\title{
In-vivo Antipyretic Effect of Eel (Anguilla bicolor bicolor) Oil on Yeast- induced Fever on Mice
}

\author{
Heru Sasongko $^{a *}$, Aulia Ayu Rahmawati ${ }^{a}$, Yeni Farida ${ }^{a}$, Sugiyarto Sugiyarto $^{b}$ \\ ${ }^{a}$ Department of Pharmacy, Faculty of Mathematics and Natural Sciences, Universitas Sebelas Maret, Jl. Ir \\ Sutami No.36 A, Kentingan, Jebres, Surakarta, Jawa Tengah 57126 \\ ${ }^{b}$ Department of Biology, Faculty of Mathematics and Natural Sciences, Universitas Sebelas Maret, Jl. Ir \\ Sutami No.36 A, Kentingan, Jebres, Surakarta, Jawa Tengah 57126 \\ * Corresponding author \\ E-mail: heru_sasongko@staff.uns.ac.id
}

DOI: 10.20961/alchemy.15.2.27086.219-227

Received 18 Januari 2019, Accepted 19 Juni 2019, Published 30 September 2019

\begin{abstract}
Fish oil has been studied for medicinal purposes, including its antipyretic properties. Eel (Anguilla bicolor bicolor) oil, which contains vitamins and fatty acids, including Omega-3 (EPA and DHA), is also expected to have the antipyretic effect. This research aimed to examine the antipyretic activity of eel oil on white mice (Mus musculus L.). An in-vivo study was done on thirty Swiss-Webster strain males mice that previously got $20 \%$ yeast-induced fever. Six treatments were applied including normal group (untreated), a negative control group (yeast-treated), a positive control group treated with acetaminophen $(1.764 \mathrm{mg} / 20 \mathrm{~g}$ body weight), and three groups treated with eel oil (0.048, 0.096 and $0.192 \mathrm{~g} / 20 \mathrm{~g}$ body weight, respectively). The data was analyzed statistically using one way ANOVA then was continued with LSD post hoc test. The results showed that eel oil has significantly reduced yeast-induced hyperthermia on mice five hours after application at doses 0.096 and $0.192 \mathrm{~g} / 20 \mathrm{~g}$ body weight. Our finding suggests that eel oil possess antipyretic properties when was applied in certain doses, and this effect is presumably attributed to its high content of fatty acid, including EPA and DHA.
\end{abstract}

Keywords: Antipyretic, Eel oil, Fever, Omega-3, DHA, EPA

\section{INTRODUCTION}

Fever is defined as an elevation of core body temperature above normal $\left(>37.7^{\circ} \mathrm{C}\right)$ centered in body thermoregulatory set-point and triggered by the presence of pyrogens (Zaino et al., 2014). As one of non-steroidal anti-inflammatory drug (NSAID), acetaminophen is commonly used for fever treatment as it possesses an antipyretic effect due to its ability to inhibit prostaglandin biosynthesis (Tesema and Makonnen, 2015). It is one of drug-induced liver injuries when it is applied in toxic dose, but it is quite safe and well-tolerated in therapeutic doses (Brune et al., 2015; James et al., 2003). 
Alternative sources of antipyretic drugs might come from marine products, especially fish oil. One of the potential alternatives is eel (Anguilla bicolor bicolor) oil. In previous studies, eel oil analysis using the heating method indicated a good quality of eel oil with appropriate standards. The oil parameters that have been studied are specific gravity value, acid value, peroxide value, saponification value, iodine value (Sasongko et al., 2017 ), and metal content (Sasongko et al., 2017 ). Eel is a type of fish that contains high protein, vitamins, and fatty acid like omega-3 (EPA and DHA) (Nafsiyah et al., 2018). Omega-3 content in eel oil is expected to be higher than omega-3 content in other fish oils (Widyasari et al., 2014; Ahn et al., 2015; Farah et al., 2018). For instance, a study reported by Widyasari et al. (2014) shows that eel oil has $5.16 \%$ omega-3. This number is considerably higher than omega-3 in milkfish oil (Chanos chanos forsskal), which only 2.4\% (Aziza, 2015).

Omega-3 content in fish oil is thought to have a significant role in reducing inflammation, pain (Sasongko et al., 2019), and fever because it can reduce prostaglandins (PGs) production in the body. It competes with arachidonic acid and also suppresses monocyte capacity to synthesize interleukin-1 (IL-1) and tumor necrosis factor (TNF) (Calder, 2013). IL-1 and TNF are the primary mediators of inflammation that can induce fever (Simopoulos, 2002). Blockage of the cyclooxygenase (COX) enzyme would inhibit the conversion of arachidonic acid to the pro-inflammatory PGs that mediates the classic inflammatory response, temperature increase (Maroon and Bost, 2006). Therefore, this research aimed to investigate the antipyretic effect of eel oil on induced fever in mice.

\section{METHODS}

\section{Material Preparation}

Acetaminophen (Kimia Farma ${ }^{\circledR}$ ) was purchased from the local pharmacy, Apotek Sebelas Maret Surakarta. Yeast was purchased from Pasar Gede Traditional Market. Other chemicals such as $\mathrm{NaOH}(\operatorname{Merck} \AA), \mathrm{Na}_{2} \mathrm{SO}_{4}$ (Merck®), methanol (Merck®) pro analytic grade, distilled water, and $\mathrm{NaCl} 0.9 \%$ were obtained from Pharmaceutical and Pharmacology Laboratory, Faculty of Mathematics and Natural Sciences, Universitas Sebelas Maret. 


\section{Experimental animal}

The experiment used 30 males of Swiss Webster mice $(20-30 \mathrm{~g})$ that were locally purchased from animal house breeding in Surakarta, Central Java. Animal handling procedures have been approved by the ethics committee of the Faculty of Medicine, Universitas Sebelas Maret.

Eel Oil

Eel oil was extracted from an average of 7 month-old Eel (Anguilla bicolor bicolor) weighing about $100-200$ grams each. The eels were purchased from eel growing center, business development unit of Universitas Sebelas Maret, Surakarta.

\section{Eel Oil Extractions}

Reflux extraction technique was performed to extract oil from fresh Eels. Eels were cut into small pieces and then refluxed using distilled water under controlled temperature $\left(70-80^{\circ} \mathrm{C}\right.$ ) for about 6 hours. The oil phase then was separated using filter paper (Sasongko et al., 2017 ${ }^{\mathrm{a}}$ ).

\section{Eel Oil Analysis}

The yielded eel oil then was analyzed for its total protein using the Kjeldahl method, a total of fatty acid using gravimetric analysis, and vitamin A and vitamin E using High-Performance Liquid Chromatography (HPLC). HPLC method was conducted in LiChrosper RP-18 column $(5 \mu \mathrm{m}), 4 \mathrm{~mm}$ x $250 \mathrm{~mm}$, at a flow rate of $1 \mathrm{~mL} / \mathrm{min}$. Methanol was used as the mobile phase, and the volume injection was $10 \mu \mathrm{L}$. Spectral profiles were sampled at a rate of 10 points/sec using 277-nm PDA detector at a column temperature of $40 \pm 15^{\circ} \mathrm{C}$. Eicosapentaenoic acid (EPA) and docosahexaenoic acid (DHA) were analyzed using gas chromatography (GC), 30 m TG-WAXMS column with FID detector at a temperature of $250{ }^{\circ} \mathrm{C}$.

\section{Antipyretic Test}

The mice were previously adapted to the new cage and given free access to food and water for one week. Food access then was restricted for 11 hours before treatments, but access to water was still given. This fasting procedure was conducted to reduce bias due to food intake.

The antipyretic test was conducted by evaluating six groups of antipyretic treatment on fever-induced mice. The treatment including normal group (untreated), a negative control group (yeast treated), a positive control group treated with acetaminophen (1.764 $\mathrm{mg} / 20 \mathrm{~g}$ body weight), and three groups treated with a different dose of eel oil ( 0.048 , 
0.096 and $0.192 \mathrm{~g} / 20 \mathrm{~g}$ body weight, respectively). Each treatment was given to a group of 5 mice.

Fever induction was carried out according to a modified method by Sengar et al. (2015). The mice were given with sub-cutan injection of $20 \mathrm{~mL} / \mathrm{kg}$ body weight (BW) of $20 \%$ yeast suspension below the nape of the neck. Body temperatures were measured in the rectal organ of mice (Souza et al., 2002) at the time before yeast induction as $t_{0}$ and 3 hours after yeast induction. Antipyretic treatment was orally given to mice that showed hyperthermia symptom (increasing body temperature). The post-induction measurement of body temperature was carried out at 1-hour interval for the first 5 hours. The serial measurements would give information about onset duration of the drug. Onset is the time needed for the drug to cause an effect.

\section{Statistical Analysis}

The effect of the six antipyretic treatments on yeast-induced fever on mice was analyzed using one-way analysis of variance (ANOVA). Priory, Shapiro-Wilks tests and homogeneity test were performed to confirm that the data were normally distributed and had homogeneity of the variances. Least significant difference (LSD) Post Hoc test was performed to determine the differences between each group of treatment.

\section{RESULTS AND DISCUSSION}

\section{Eel Oil Analysis}

The results showed that eel oil contains a high percentage of total fatty acid compounds, up to $88.43 \% \mathrm{w} / \mathrm{w}$ (Table 1). This value more than different marine fish species like forkbeard (40.5\%), Atlantic cod (44.3\%), European pilchard (18 \%), Atlantic mackerel (12.4\%), great weever (68.9\%), etc. (Guil-Guerrero et al., 2011). Eel oil has been known for its high content of saturated fatty acids (SAFA), monounsaturated fatty acid (MUFA), and polyunsaturated fatty acid (PUFA) (Nafsiyah et al., 2018). As much as $0.8 \%$ w/w EPA and $4.17 \%$ w/w DHA was also measured in the Eel oil. The EPA and DHA are thought to provide an antipyretic effect, providing anti-inflammation activity through inhibition of prostaglandin biosynthesis (Camuesco et al., 2005; Mullen et al., 2010).

\section{Antipyretic Effect}

In this research, yeast induction had successfully triggered hyperthermia on mice by increasing the average rectal temperature of about $1{ }^{\circ} \mathrm{C}$, three hours after administration 
(except the normal group which not treated with yeast). Yeast contains $S$. cerevisiae and could increase rectal temperature through the synthesis of prostaglandins (Ghauri et al., 2017).

Table 1. Measured total protein, fatty acid, and vitamins compounds of Eel oil.

\begin{tabular}{lc}
\hline \multicolumn{1}{c}{ Parameters } & Results \\
\hline Total protein (TP) & $0.19 \% \mathrm{w} / \mathrm{v}$ \\
Total of fatty acid (TFA) & $88.43 \% \mathrm{w} / \mathrm{w}$ \\
Eicosapentaenoic acid (EPA) & $0.8 \% \mathrm{w} / \mathrm{w}$ \\
Docosahexaenoic acid (DHA) & $4.17 \% \mathrm{w} / \mathrm{w}$ \\
Vitamin A (retinol equivalent) & $981.49 \mathrm{mcg} / 100 \mathrm{~g}$ \\
Vitamin E & not detected \\
\hline
\end{tabular}

The antipyretic treatments with acetaminophen, eel oil $0.096 \mathrm{~g} / 20 \mathrm{~g} \mathrm{BW}$ and 0.192 $\mathrm{g} / 20 \mathrm{~g} \mathrm{BW}$ displayed a decrease of hyperthermia-induced rectal temperature in the first hour of oral treatment. Meanwhile, mice treated with eel oil $0.048 \mathrm{~g} / 20 \mathrm{~g} \mathrm{BW}$ and yeast treatment (negative control) showed a later temperature decrease in the second and third hour. At last, the rectal temperature of not treated mice considerably showed little changes (Figure 1).

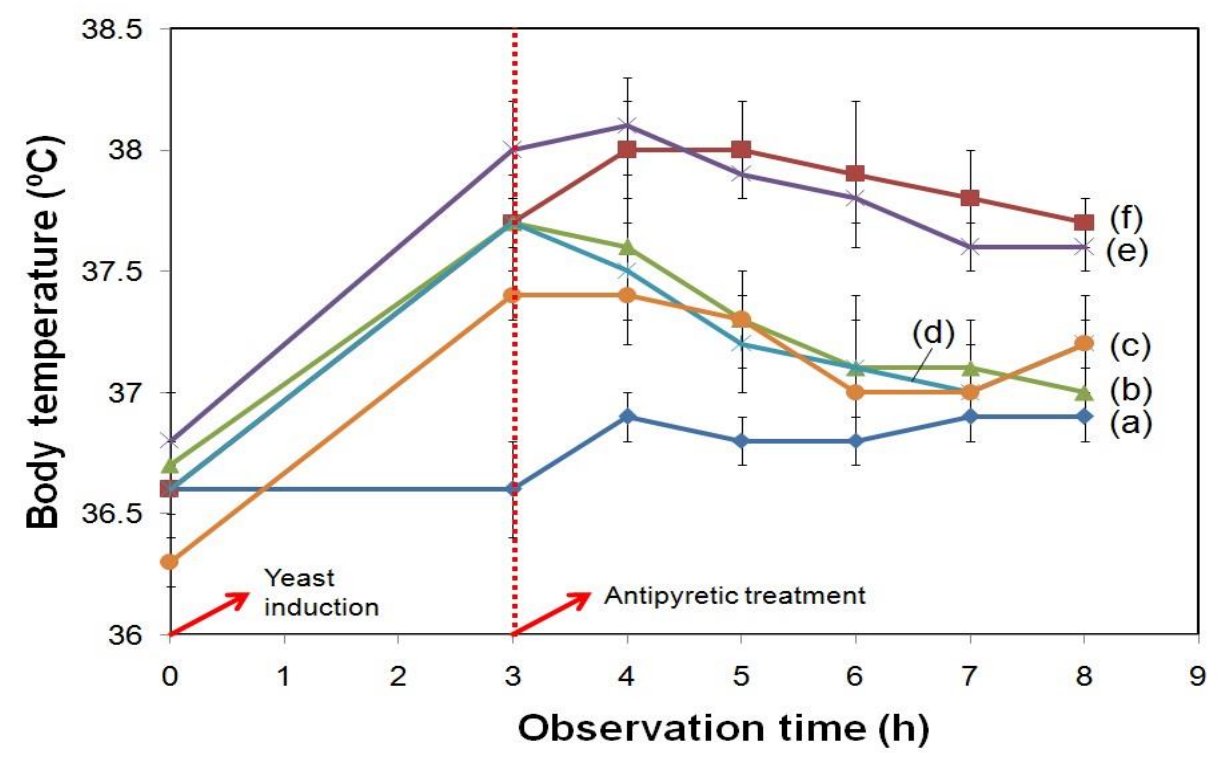

Figure 1. The changes of mice body temperature $\left({ }^{\circ} \mathrm{C}\right.$ ) after yeast injection of (a) normal group, (b) acetaminophen treatment group, antipyretic treatment group with eel oil (c) $0.192 \mathrm{~g} / 20 \mathrm{~g} \mathrm{BW}$, (d) $0.096 \mathrm{~g} / 20 \mathrm{~g} \mathrm{BW}$, (e) $0.048 \mathrm{~g} / 20 \mathrm{~g} \mathrm{BW}$, and (f) negative control group.

Acetaminophen, as a positive control, showed better body temperature reduction compared to other treatments. Acetaminophen is a non-steroid anti-inflammatory drug 
(NSAIDs) that inhibits the activity of the enzyme called cyclooxygenase (COX) which leads to the formation of prostaglandins (PGs) that causes fever (Aronoff and Neilson, 2001; Graham and Scott, 2005). In the positive control treatment, the decrease in body temperature started from 1-hour after drug administration. According to Raffa et al., (2014), this rapid effect is related to the pharmacokinetics of acetaminophen in which can be rapidly absorbed by the digestive tract. The peak serum level is achieved in 30-60 minutes with a half-life of 2 hours (Raffa et al., 2014).

Table 2. Mice body temperature changes before and after oral antipyretic treatment as a result of LSD post hoc test.

\begin{tabular}{|c|c|c|c|c|c|c|c|}
\hline \multirow{2}{*}{ Groups } & \multicolumn{7}{|c|}{$\begin{array}{c}\text { Observation Time } \\
\text { (Time (hour) } \pm \text { standart eror of means }(\mathrm{SEM}) \text { ) }\end{array}$} \\
\hline & $0^{\#}$ & 3 & 4 & 5 & 6 & 7 & 8 \\
\hline Normal Group & $36.6 \pm 0.2$ & $36.6 \pm 0.2$ & $36.9 \pm 0.1 *$ & $36.8 \pm 0.1 *$ & $36.8 \pm 0.1 *$ & $36.9 \pm 0.1 *$ & $36.9 \pm 0.1 *$ \\
\hline $\begin{array}{l}\text { Negative } \\
\text { Control Group }\end{array}$ & $36.6 \pm 0.1$ & $37.7 \pm 0.2$ & $38.0 \pm 0.2$ & $38.0 \pm 0.2$ & $37.9 \pm 0.3$ & $37.8 \pm 0.2$ & $37.7 \pm 0.1$ \\
\hline $\begin{array}{l}\text { Acetaminophen } \\
1.764 \mathrm{mg} / 20 \mathrm{~g} \\
\text { BW }\end{array}$ & $36.7 \pm 0.1$ & $37.7 \pm 0.1$ & $37.6 \pm 0.3 *$ & $37.3 \pm 0.2 *$ & $37.1 \pm 0.2 *$ & $37.1 \pm 0.2 *$ & $37.0 \pm 0.1 *$ \\
\hline $\begin{array}{l}\text { Eel oil } 0.048 \mathrm{~g} \\
/ 20 \mathrm{~g} \mathrm{BW}\end{array}$ & $36.8 \pm 0.2$ & $38.0 \pm 0.2$ & $38.1 \pm 0.2$ & $37.9 \pm 0.1$ & $37.8 \pm 0.1$ & $37.6 \pm 0.1$ & $37.6 \pm 0.1$ \\
\hline $\begin{array}{l}\text { Eel oil } 0.096 \mathrm{~g} \\
/ 20 \mathrm{~g} \mathrm{BW}\end{array}$ & $36.6 \pm 0.4$ & $37.7 \pm 0.3$ & $37.5 \pm 0.2^{*}$ & $37.2 \pm 0.2 *$ & $37.1 \pm 0.3 *$ & $37.0 \pm 0.2 *$ & $37.2 \pm 0.2 *$ \\
\hline $\begin{array}{l}\text { Eel oil } 0.192 \mathrm{~g} \\
/ 20 \mathrm{~g} \mathrm{BW}\end{array}$ & $36.3 \pm 0.1$ & $37.4 \pm 0.1$ & $37.4 \pm 0.2^{*}$ & $37.3 \pm 0.1 *$ & $37.0 \pm 0.1 *$ & $37.0 \pm 0.2 *$ & $37.2 \pm 0.1^{*}$ \\
\hline
\end{tabular}

The eel oil treatment with a dose of $0.048 \mathrm{~g} / 20 \mathrm{~g}$ BW showed little decrease in body temperature but the difference was not significant compared to the negative control group ( $p>0.05)$, meaning that this dose one has not been able to show a clear antipyretic effect on fever-induced mice (Table 2). Presumably, the dose has not reached the minimum effective level to give a significant result (Benet et al., 1996). While in the doses of 0.096 $\mathrm{g} / 20 \mathrm{~g} \mathrm{BW}$ and $0.192 \mathrm{~g} / 20 \mathrm{~g} \mathrm{BW}$, the antipyretic effect was clearly shown as it was significantly different with the negative control group and the temperature decrease was comparable with the positive control of acetaminophen treatment (Table 2). This antipyretic effect might be attributed to the EPA and DHA contents in eel oil. EPA and DHA are included in the essential fatty acids that are released if there is wound on cell membranes and then competitively inhibit the formation of pro-inflammatory interleukins (IL-1 $\beta$, IL-6, and IL-12), $\alpha$ factor necrosis factor (TNF $\alpha$ ) and prostaglandin (Tesema and Makonnen, 2015). This inhibition of prostaglandins biosynthesis is believed to be the main 
key to the antipyretic effect of eel oil as prostaglandin is involved in the regulation of body temperature (Tesema and Makonnen, 2015). Omega 3 especially EPA has a long-chain structure equation with arachidonic acid (AA), thus it can be a competitor to replace arachidonic acid in the metabolic processes of cyclooxygenase (COX) and lipoxygenase (Kobayashi et al., 2006). This theory is strengthened by another study by Laino (2017), suggested that EPA can inhibit the COX mechanism, therefore, prostaglandins are not formed. Blockage of the COX enzyme would inhibit the conversion of AA to the proinflammatory PGs that mediate fever (Maroon and Bost, 2006).

\section{CONCLUSION}

Eel oil treatment at doses of 0.096 and $0.192 \mathrm{~g} / 20 \mathrm{~g} \mathrm{BW}$ had shown a clear antipyretic effect and comparable to a common antipyretic drug, acetaminophen. However, the effect was not clear at dose $0.048 \mathrm{~g} / 20 \mathrm{gr} \mathrm{BW}$. This finding indicates that the administration of eel oil on fever-induced mice should meet the minimum doses to give a significant effect. The effect is thought to be the result of prostaglandins biosynthesis inhibition by DHA and EPA.

\section{ACKNOWLEDGMENTS}

All authors would like to thank Universitas Sebelas Maret, which has funded this research with the continued fundamental PNBP grants scheme 2019.

\section{REFERENCES}

Ahn, J.C., Chong, W.S., Na, J.H., Yun, H.B., Shin, K.J., Lee, K.W., and Park, J.T., 2015. An Evaluation of Major Nutrients of Four Farmed Freshwater Eel Species (Anguilla japonica, A. rostrata, A. bicolor pacifica and A. marmorata). Korean Journal of Fisheries and Aquatic Sciences 48(1), 44-50. doi : 10.5657/KFAS.2015.0044.

Aronoff, D.M., and Neilson, E.G., 2001. Antipyretics: Mechanisms of Action and Clinical Use in Fever Suppression. The American Journal of Medicine 111(4), 304-315. doi : 10.1016/S0002-9343(01)00834-8.

Aziza, I.N., 2015. Perbandingan Kandungan Omega 3 dalam Minyak Ikan Bandeng (Chanos chanos Forsskal) yang Segar dengan Ikan Bandeng yang dikeringkan di Pasar. Thesis. Fakultas Matematika dan Ilmu Pengetahuan Alam Universitas Islam Bandung (UNISBA).

Benet, L.Z., Kroetz, D., Sheiner, L., Hardman, J., and Limbird, L., 1996. Pharmacokinetics: The Dynamics of Drug Absorption, Distribution, Metabolism, 
and Elimination. Goodman \& Gilman's The Pharmacological Basis of Therapeutics. 3-27.

Brune, K., Renner, B., and Tiegs, G., 2015. Acetaminophen/Paracetamol: A History of Errors, Failures and False Decisions. European Journal of Pain 19(7), 953-965. doi : 10.1002/ejp.621.

Calder, P.C., 2013. Omega-3 Polyunsaturated Fatty Acids and Inflammatory Processes: Nutrition or Pharmacology. British Journal of Clinical Pharmacology 75(3), 645662. doi: 10.1111/j.1365-2125.2012.04374.x.

Camuesco, D., Gálvez, J., Nieto, A., Comalada, M., Rodríguez-Cabezas, M.E., Concha, A., Xaus, J., and Zarzuelo, A., 2005. Dietary Olive Oil Supplemented with Fish Oil, Rich in EPA and DHA (n-3) Polyunsaturated Fatty Acids, Attenuates Colonic Inflammation in Rats with DSS-Induced Colitis. The Journal of Nutrition 135(4), 687-694. doi: 10.1093/jn/135.4.687.

Farah, K., Gunawan, I.R., Putra, G.B., Agustono, Lokapirnasari, W.P., Lamid, M., Masithah, E.D., Nurhajati, T., and Rozi, 2018. Effect of Earthworm (Lumbricus rubellus) in Feed Formulation to Improve Fatty Acids Profile in Eel (Anguilla bicolor) Meat. IOP Conference Series: Earth and Environmental Science 137, 12032. doi :10.1088/1755-1315/137/1/012032.

Ghauri, M.A., Khan, G.J., Khan, S., Javeed, A., Naeem, H.S., and Ashraf, M., 2017. InVivo Evaluation of Analgesic, Anti-Inflammatory and Anti-Pyretic Activity of Aqueous Methanolic Extract of Jatropha gossypifolia. African Journal of Pharmacy and Pharmacology 11(30), 355-361. doi: 10.5897/AJPP2017.4812.

Graham, G.G. and Scott, K.F., 2005. Mechanism of Action of Paracetamol. American Journal of Therapeutics 12(1), 46-55.

Guil-Guerrero, J.L., Venegas-Venegas, E., Rincón-Cervera, M.Á., and Suárez, M.D., 2011. Fatty Acid Profiles of Livers from Selected Marine Fish Species. Journal of Food Composition and Analysis 24(2), 217-222. doi: 10.1016/j.jfca.2010.07.011.

James, L.P., Mayeux, P.R., and Hinson, J.A., 2003. Acetaminophen-Induced Hepatotoxicity. Drug Metabolism and Disposition 31(12), 1499-1506. doi: 10.1124/dmd.31.12.1499.

Kobayashi, N., Barnard, R.J., Henning, S.M., Elashoff, D., Reddy, S.T., Cohen, P., Leung, P., Hong-Gonzalez, J., Freedland, S.J., Said, J., Gui, D., Seeram, N.P., Popoviciu, L.M., Bagga, D., Heber, D., Glaspy, J.A., and Aronson, W.J., 2006. Effect of Altering Dietary $\omega-6 / \omega-3$ Fatty Acid Ratios on Prostate Cancer Membrane Composition, Cyclooxygenase-2, and Prostaglandin E2. Clinical Cancer Research 12, 4662-4670. doi: 10.1158/1078-0432.CCR-06-0459.

Laino, C.H., 2017. Innovations in Pain Management: Morphine Combined with Omega-3 Fatty Acids. The Open Conference Proceedings 8, 52-65. doi: $10.2174 / 221028901708010052$.

Maroon, J.C. and Bost, J.W., 2006. $\omega-3$ Fatty Acids (Fish Oil) As An Anti-Inflammatory: An Alternative to Nonsteroidal Anti-Inflammatory Drugs for Discogenic Pain. Surgical Neurology 65, 326-331.

Mullen, A., Loscher, C.E., and Roche, H.M., 2010. Anti-Inflammatory Effects of EPA and DHA are Dependent Upon Time and Dose-Response Elements Associated with 
LPS Stimulation in THP-1-Derived Macrophages. The Journal of Nutritional Biochemistry 21, 444-450.

Nafsiyah, I., Nurilmala, M., and Abdullah, A., 2018. Nutrient Composition of Eel Anguilla bicolor bicolor and Anguilla marmorata. Jurnal Pengolahan Hasil Perikanan Indonesia 21, 504-512.

Raffa, R.B., Pergolizzi, J.V., Taylor, R., Decker, J.F., and Patrick, J.T., 2014. Acetaminophen (Paracetamol) Oral Absorption and Clinical Influences. Pain Practice 14, 668-677.

Sasongko, H., Efendi, N.R., Budihardjo, A., Farida, Y., Amartiwi, T., Rahmawati, A.A., Wicaksono, A., and Sugiyarto, 2017 . Solvent and Extraction Methods Effects on The Quality of Eel (Anguilla bicolor) Oil. Journal of Physics: Conference Series $795,12021$.

Sasongko, H., Sugiyarto, S., Budiharjo, A., and Efendi, N.R., 2017 . AntiHypercholesterolemia Effects and Quality of Eel (Anguilla bicolor) oil. International Journal of Science and Applied Science: Conference Series 2, 174180.

Sasongko, H., Kusumastuti, N.I., Alifa, G.R., and Rahmawati, A.A., 2019. In-Vivo Analgesic and Anti-Inflammatory Effects of Eel (Anguilla bicolor bicolor) Oil. Pharmaciana 9, 59-70.

Sengar, N., Joshi, A., Prasad, S.K., and Hemalatha, S., 2015. Anti-Inflammatory, Analgesic and Anti-Pyretic Activities of Standardized Root Extract of Jasminum sambac. The Journal of Ethnopharmacology 160, 140-148.

Simopoulos, A.P., 2002. Omega-3 Fatty Acids in Inflammation and Autoimmune Diseases. Journal of the American College of Nutrition 21, 495-505.

Souza, F.R., Souza, V.T., Ratzlaff, V., Borges, L.P., Oliveira, M.R., Bonacorso, H.G., Zanatta, N., Martins, M.A.P., and Mello, C.F., 2002. Hypothermic and Antipyretic Effects of 3-Methyl- and 3-Phenyl-5-Hydroxy-5-Tichloromethyl-4,5-Dihydro-1HPyrazole-1-Carboxyamides in Mice. The European Journal of Pharmacology 451, 141-147.

Tesema, S.H. and Makonnen, E., 2015. In-Vivo Analgesic and Antipyretic Activities of NButanol and Water Fractions of Ocimum sauve. Ethiopian Journal of Health Sciences 25, 139-146.

Widyasari, R.A.H.M., Kusharto, C.M., Wiryawan, B., Wiyono, E.S., Suseno, S.H., 2014. Nutritive Value and Fatty Acids Profile of Fresh Indonesian Eel (Anguilla bicolor) and Kabayaki. Malaysian Journal of Health Sciences 12(1). doi: 10.17576/jskm1201-2014-06.

Zaino, Q., Hidayat, E.M., and Peryoga, S.U., 2014. Antipyretic Effect of Cinnamomum burmannii (Nees \& T.Nees) Blume Infusion in Fever-induced Rat Models. Althea Medical Journal 1, 100-104. 